\title{
Relevansi Amandemen UUD 1945 terhadap Tuntutan Era Globalisasi
}

\author{
Jawahir Thontowi
}

\begin{abstract}
Abstrak
Political practice, both in the periods of the Old Regime and New Regime, did not reflect the implementation of Rule of Law principles. Govemment system tended to be constitutionalism authoritarian, indicated by an abundance of legislation justfying government policies. The amandement of the Constitution of 1945, Therefore, has been relevant in the era of globalization not only for the sake of human right protection, good relationship among of ethnics, religions and group sas well as of universal values, but also for the sake of greater assurance to form the supremacy of law.
\end{abstract}

\section{Pendahuluan}

- Sistem hukum di suatu negara tidak pernah hanya mengacu kepada unifikasi dan kodifikasi hukum yang mutlak. Hukum kebiasaan masyarakat selain hukum negara, dan juga norma-norma hukum keagamaan masih turut berkembang. Misalnya, Merry menegaskan bahwa suatu negara mengenal hukum kolonial (Eropa-Belanda) untuk menciptakan ketertiban, juga tidak bisa mengesampingkan kompleksitas sistem hukum sebelumnya.' Sebagai kelanjutan dari kemerdekaan kolonialis- me Belanda, UUD 1945 dirasakan masih kurang memadai. Sehingga amandemen menjadi tuntutan baru dalam era reformasi yang tidak bisa lepas dari usaha penyesuaian diri dengan nilai-nilai dan tuntutan arus globalisasi. Robertson menyebutkan tiga aspek penting globalisasi yang seyogyanya dipertimbangkan setiap negara. ${ }^{2}$

Perfama, masyarakat nasional yang cenderung semakin hari cenderung menempatkan heterogenitas yang secara internal dan

'Sally Engle Merry. 1988. “Legal Pluralism". Law and Society Riview. Vol 22/5. Hlm. 869.

2Robertson, Roland. After Nostalgia? Wilful Nostalgia and the phases of Globalization in Turner. Bryans (ed). Theories of Modernity and Post-modernity. London Sage Publications. HIm. 57. 
eksternal, dan pada waktu yang sama, mereka mengalami suatu desakan untuk membangun kembali identitas masing-masing sepanjang garis cenderung kebinekaan. Kedua, individu yang cenderung sebagai subjek dari suatu persaingan suku, budaya dan keagamaan. Hans Kung menegaskan No world peace without religious pease. Global analyses and perspectives on the religious situation of humankind. ${ }^{3}$ Ketiga yaitu sistem hubungan internasional (the system of international relation) yang makin menyebar.

Persoalan hak azasi manusia akan selalu menjadi isu sensitif masyarakat internasional bilamana UUD 1945 mengabaikan tegaknya perlindungan hak-hak dasar masyarakat. Namun, perlu kiranya ditinjau terlebih dahulu bagaimana prinsip-prinsip tegaknya negara hukum agar cita-cita amandemen 1945 memiliki landasan kuat dalam merespon arus global.

\section{Prinsip - Prinsip Negara Hukum}

Sebagaimana disebutkan dalam Pembukaan UUD ' 45, bahwa Indonèsia berdasarkan negara hukum (rechtsstaaf) dan bukan merupakan negara kekuasaan (machtsstaat). Namun cita-cita tersebut dalam pengalaman ketatanegaraan pemerintahan Orde Lama dan Orde Baru terlihat tidak konsisten.

Timothy O'Hogan, di dalam bukunya The End of Law menjelaskan beberapa ciri negara hukum. Pada dasarnya, rechsstaat mengan- dung elemen-elemen kebebasan individual melalui prosedur hukum yang dilaksanakan di pengadilan dan dibarengi dengan alat paksa dalam melaksanakan misinya untuk menekan timbulnya absolutisme. "The rechtsstaat can be defined as a society ruled by procedural justice and guaranteing the universal and equal distribution of basic constitutional rights of citizens" ${ }^{4}$ Suatu negara berdasarkan hukum mengharuskan penyelenggaraan negara menerapkan kekuasaan dengan cara-cara yang adil dengan menjamin terselenggaranya pembagian hak-hak dasar universal masyarakat secara sejajar.

Penulis lain, A.V Dicey di dalam bukunya Law and the Constitution menyebutkan the rule of law atau rechtsstaat menegaskan; Pertama, the rule of law harus diselenggarakan dalam suatu pemerintahan yang mengutamakan supremasi hukum dan menghindarkan kekuasaan yang sewenang-wenang. Kedua, the rule of law harus menempatkan kesederajatan untuk mentaati peraturan hukum (equality befor the law). Ajaran ini mengharuskan setiap permasalahan diselesaikan melalui peradilan dengan menolak adanya hak-hak istimewa.

Senada dengan itu, Phillipus M. Hadjon mengajukan empat syarat-syarat dasar rechtsstaat suatu ide yang secara langsung dipengaruhi hukum Belanda.

1. Asas legalitas, setiap tindakan pemerintahan harus didasarkan atas dasar peraturan perundang-undangan (wettelijke Grondsiag).

3Untuk lebih detil lihat Hans Kung. 1991. Global Responsibility: In Search of a New World Ethics. New York: Crossroad. HIm. 109.

${ }^{4}$ Rechtsstaat (German) atau the nule of law (Inggris) telah diperjuangkan sejak abad ke 17 di Inggris. O'Hogan 1984. The End of Law. Oxford. Basill Blackwell. Hlm 131. 
2. Pembagian kekuasaan, syarat ini mengandung makna bahwa kekuasaan negara tidak baik hanya bertumpu pada suatu tenaga.

3. Hak-hak dasar (groundrechten), hak-hak - dasar merupakan sasaran perlindungan hukum bagi rakyat dan sekaligus membatasi pembentukan undang-undang.

4. Pengawasan pengadilan, bagi rakyat tersedia saluran melalui pengadilan yang bebas untuk menguji keabsahan tindakan pemerintah. $^{5}$

Bilamana prinsip-prinsip negara hukum di atas dikaitkan dengan tragedi sejarah ketatanegaraan pada masa Orde Baru, maka usahausaha menjadikan Pancasila dan UUD 1945 sebagai suatu ideologi bangsa dan negara disakralkan merupakan penyimpangan. $\mathrm{Pe}$ nataran P4 merupakan salah satu cara penggembosan hak-hak azasi rakyat dan pemujaan terhadap kedudukan penyelenggaraan negara atau pemerintah. Hal tersebut merupakan prinsip-prinsip negara hukum.

Proses sakralisasi terhadap Pancasila dan UUD 1945, bukan sekedar memberi legitimasi munculnya pemerintahan autoritarian constitutionalisme, melainkan juga terdapat aspek dalam batang tubuh UUD 45 dapat disalahtafsirkan.

Democracy clearly limits power only with respect to majoritarian politics and decision making, and is silent on many issues regarding human rights and restrain of power. Constitutionalisme mirors less trust in democratic process and human nature, and more reliance on laws and institutions which set parameters of legitimate goverment action. Like a democracy, a constitutionalist system may become authoritarian, with or with out a change in the written constitution or alvowed public ideologiy. The configuration of laws, structures, social culture, economy, politics and public values making up each nation's contitutional culture is its own. ${ }^{6}$

Menggunakan hukum sebagai alat pengesahan atas kemauan negara atau pemerintahan, telah terbukti tidak efektif dalam menekan timbulnya konflik sosial yang berkepanjangan, baik yang terjadi antara masyarakat dan negara atau masyarakat dengan masyarakat. Banyaknya UU yang dibuat oleh pemerintah dan lembaga legislatif di masa Orde Baru terbukti tidak identik dengan usaha mewujudkan negara hukum. Kehendak penguasa atau pemerintah melalui hadirnya peraturan perundangan acap kali mengabaikan tegaknya hak-hak azasi rakyat.

\section{Amandemen dan Aspirasi Nasional}

Kesadaran untuk mengakui bahwa there is no a perfect law, but we agree to adhere the law we made, begitu relevan untuk dipertim-

5Philipus M. Hadjon. 1996. “Ide Negara Hukum dalam Sistem Ketatanegaraan Republik Indonesia”. Dalam Bagir Manan (ed). Bagian Kedaulatan Rakyat Hak Asasi Manusia dan Negara Hukum. Kumpulan Esai Guna Menghormati R Sri Soemantri Marto Soewigyó. Jakarta: GMP. HIm 78-79.

${ }^{8}$ Beer, lawrence W. ND. Constitutional Systems in Late Twentieth Century Asia. London. Univercity of Washington Press. HIm. 13. 
bangkan. Dengan begitu, telah dibuat amandemen UUD 1945, tetap akan tidak berart banyak bilamana kita tidak dibarengi dengan kejujuran dan amanah atau komitmen terhadap janji.

Untuk sekedar menyebut beberapa aspek vital.yaitu, menyangkut pembatasan kekuasaan Mandataris terhadap kedudukan dan susunan MPR/DPR. "Bahwa susunan keanggotaan MPR (juga DPR) ditetapkan dengan undangundang", Ketentuan yang singkat ini tidak lazim ditemukan dalam konstitusi negara-negara lain pada umumnya, sebab malah membuka peluang bagi mandataris untuk ikut menentukan susunan keanggotaan badan ini. ${ }^{7}$

Ketentuan Pasal 1 ayat (2) UUD 1945 yang menentukan bahwa di mana kedaulatan rakyat sepenuhnya dijalankan oleh MPR terbukti tidak sesuai dengan nilai-nilai demokrasi yang diakui negara-negara maju. Sebab bilamana, UUD 1945 itu dipercayai sebagai konstitusi, maka konsekuensinya pembagian kekuasaan antara lembaga politik yang satu dengan yang lainnya harus tegas.

Rumusan normatif mengenai negara hukum yang berdasarkan kedaulatan rakyat seperti disebut oleh UUD 1945 itu, dalam pelaksanaannya dapat melakukan penyimpangan. Di pihak lain rakyat melalui wakilnya di DPR tidak memperoleh kemudahan dalam melakukan pengawasan. Anggota MPR (dan juga DPR) ditetapkan dengan undang-undang yang singkat ini tidak lazim ditemukan dalam kontitusi negara-negara lain pada umumnya membuka peluang bagi mandataris untuk ikut menentukan suasana keanggotaan badan itu.
Secara konstitusional, tidak ada alasan yang dapat dipertahankan untuk menjadikan UUD 1945 sebagai kitab suci. Seorang orator dari Yunani, Demothenes (384 - 322 BC) ${ }^{8}$ mengajukan pandangannya mengenai fungsi hukum di hadapan para juri sebagai berikut;

Law desires what is just and honourable and usefui; They seek for there is, and, when it is found, it is set forth a general ordinance, the same and alike for all and that is law, which all men ought to obey for many reasons, and especially because every law is an invention and gift of the gods, a resolution of wise men, a corrective of errors intentional and unintentional, a compact all who belong to the state ought to live.

Tujuan tegaknya hukum adalah tercapainya keadilan, kehormatan, martabat serta kemanfaatan. Kedua, dilihat dari sistem norma dan fungsinya, hukum itu sebagai temuan atau hadiah dari Tuhan, suatu putusan dari orangorang yang bijak, berfungsi sebagai suatu alat yang mengkoreksi kesalahan-kesalahan seseorang secara sengaja atau tidak, yang berlaku pada suatu negara. Ketiga, dari segi penegakannya, hukum suatu pedoman dan perintah mewajibkan semua orang untuk mematuhinya untuk berbagai alasan, oleh karena itu semua warga negara dan sesamanya adalah sederajat di depan hukum.

Jadi, bilamana ketiga dasar tersebut-akan dijadikan acuan, maka aspek kedaulatan

'Yusril Ihza Mahendra. 1996. Dinamika Tatanegara Indonesia. Jakarta: Gema Insan Press. Him. 42.

'LihatR.H, Hiclking. 1995. Major Legal System. Australia Center for SoutheastAsian Law. Faculty of Law. Northen Trerritory University. HIm 18. 
rakyat melalui MPR tidak independen. Intervensi presiden terhadap tembaga eksekutif dan judisial tidak bisa ditolelir. Pasal-pasal tersebut bukan saja telah menciptakan pemusatan kekuasaan di tangan seseorang melainkan juga berakibat lembaga legislatif dan judisial semakin inferior.

Sistem pemerintahan check and balance tidak akan tercipta. Salah satu akibat, berpusatnya kedudukan di tangan presiden telah terbukti prinsip kesederajatan hukum tidak bisa dilaksanakan. Dalam kaitannya dengan pimpinan nasional misainya, Tap MPR No. XI/ MPR/1998 tidak dapat dilaksanakan secara efektif untuk membawa mantan Presiden Suharto ke pengadilan atas dugaan keterlibatannya dalam KKN. Daniel S Lev, mengisyaratkan bahwa ide untuk membawa Suharto ke pengadilan juga tidak banyak artinya. Setelah itu, akan terjadi hal yang sama bila tidak memperbaiki sistemnya. Jadi, mengubah sistem (politik dan hukum) tentu harus lebih diutamakan. ${ }^{9}$

Preseden semacam ini juga pernah terjadi dan dialami terhadap mantan Presiden Sukarno. Perlunya masyarakat menghormati mereka sebagai bapak bangsa menjadi faktor penghambat dilaksanakan kesederajatan hukum. Oleh karena itu, tidak aneh jika sindiran Hickling, yaitu the concept of supremacy of law is not prevalent in all Asian societies a p/erson status has taken into cansi deration..$^{10}$ Mungkin sama halnya, dengan pribahasa Jawa sinten lalu pinten dalam penerapan hukum yang diskriminatif. Artinya kedudukan seseorang jauh lebih menentukan ketimbang peraturan hukum.

Sifat diskriminasi itu, sesungguhnya secara konvensional dan umumnya telah didukung oleh Pasal 131 (Indische Staatsregeling). Kedudukan non pribumi (Tionghoa) yang minoritas, disejajarkan situasi hukumnya dengan golongan Eropa, Belanda dan Timur Asing juga telah memberikan andil terhadap melembaganya anasir-anasir hukum yang diskriminatif sebagaimana ditemukan dalam UUD 45 dan peraturan perundang-undangan lainnya."

Contoh lain, tindakan presiden memberhentikan pejabat-pejabat petinggi hukum yang menyuarakan kebenaran dan keadilan, tanpa diproses secara hukumi karena dianggap tidak setia terhadap pemerintahan status quo. Dalam aspek pelaksanaan peradilan, UUD 45 dan UU No14/tahun 1974 telah mengatur banyak hal mengenai.administrasi peradilan. Akan tetapi mengenai kepastian hukum bagi hakim relatif rentan. Pertama, Indonesia mengakui pluralisme hukum sehingga hakim mempunyai kebebasan untuk membuat pertimbangan dan suatu putusan. Hanya saja hal itu akan tegak bilamana hakim-hakim itu memiliki watak dan moral malaikat, yaitu amanah dan adil. Kedua, doktrin preseden hukum (Jurisprudensi) yang mengikat hakimhakim terhadap putusan dapat dipergunakan atas kasus-kasus yang memiliki kesamaan.

${ }^{9}$ Daniel S.Lev. KOMPAS. September: 1999

${ }^{10}$ Hickling. Op. Cit.

"Penjelasan lengkap mengenai pengaruh Pasal 131 terhadap peraturan hukum yang diskriminatif dapat dilihat dalam J. Thontowi. 1997. Law and Custom: The Interaction of Local Custom and the Indonesian Legal System in Dispute Resolutions. Ph.D Thesis. Department of Anthropology. UWA. Nedlands. 
Hal ini penting untuk dijadikan prinsip dalam menegakkan kepastian hukum. Jurisprudensi berguna sebagai suatu parameter menegakkan kebenaran hukum bagi hakim-hakim tingkat PN dan PT. Lemahnya teori preseden hukum tidak akan efektif bilamana hakim-hakim Agung juga tidak menegakkan kebenaran dan keadilan hukum.

Mengajukan doktrin preseden hukum bagi sistem peradilan bukan persoalan baru di Indonesia. Dalam hukum adat Indonesia telah menganut doktrin preseden hukum. $\mathrm{Na}$ mun, karena pengaruh hukum Belanda, maka hukum sipil indonesia telah meninggalkan teori preseden hukum. The introduction of the idea of precedent by Ter Haar illustrates an inherent contradiction in Dutch colonial legal though. While there was conscious policy to preserve and administer indigeneous law, this was always subject to the dominant of the European state system and legal system.? Dengan kata lain tergesernya teori preseden hukum dalam hukum kebiasaan Indonesia karena pengaruh hukum Belanda yang sampai kini tidak mudah dimunculkan kembali.

\section{Aspirasi Individu, Suku dan Agama}

Kenyataan Indonesia sebagai negara kesatuan, terdiri dari berbagai suku, bangsa dan agama yang berbeda-beda telah melahirkan perubahan sikap yang mendasar terhadap rasa dan jiwa nasionalisme. Timbulnya isu disintegrasi telah mengancam eksistensi negara kesatuan Indonesia. Salah satunya disebabkan karena UUD 1945 tidak bisa dijadikan ins- trumen hukum efektif dalam menciptakan timbulnya proses interaksi sosial, di mana semua pihak terlayani secara seimbang, pantas dan adil. Keberadaan hukum substantif, baik yang berada dalam batang tubuh UUD 1945 , khususnya mengenai otonomi daerah, dan juga UU mengenai pemilikan tanah dan perlindungan terhadap hak-hak masyarakat memang belum mengakomodasikan arus globalisasi terutama yang berkaitan dengan fungsi peraturan hukum yang mampu menekan timbulnya konflik yang diakibatkan oleh motifmotif individu suku dan agama.

Memudarnya semangat persatuan Indonesia, dan meningkatnya tuntutan kelompokkelompok sosial, kesukuan, dan keagamaan ini juga disebabkan oleh terbentuknya pemusatan kekuasaan. Tuntutan Otonomi Daerah dalam pengaturan anggaran belanja 'semakin membuktikan adanya hubungan yang erat antara keinginan menetapkan federal sebagai bentuk yang ideal lebih dari itu daerah-daerah tertentu, seperti Aceh dan Irian Jaya. Banu-baru ini, UU mengenai perimbangan otonomi daerah telah dibuat. Apakah sesuai dengan tuntutan keadilan adalah sangat tergantung kepada penyelenggara dan aparat pemerintah secara keseluruhan.

Timbulnya kecemburuan sosial antara kelompok suku-suku, khususnya pendatang (migrasi) dan penduduk asli, antara kelompok minoritas tionghoa, sebagi produsen dan mayoritas muslim sebagai konsumen merupakan faktor-faktor sensitif bagi timbulnya konflik sosial dan politik. Saat ini, di luar institusi pemerintah telah muncul Lembaga Pengawasan

12Hooker. 1978. A Consice Legal History of Southeast Asia. Oxford: Clarendon Press. Hlim. 193. 
Obat dan Makanan Majelis Ulama Indonesia (LPOM MUI), yang secara juridis berfungsi melindungi konsumen Islam. Dampaknya terhadap situasi tertib bagi masyarakat Islam (mayoritas) dan produsen tionghoa (minoritas) jelas positif. Timbulnya aspirasi Islam dalam aspek label makanan halal jelas-jelas mencerminkan lahirnya institusional formal selain negara, yang melindungi hak-hak keimanan kaum muslimin.

Dari kedua contoh di atas, baik yang bersifat horizontal seperti konflik yang bersifat. vertikal, seperti antara otonomi daerah dan pusat, disadari atau pun tidak, membuktikan bahwa UUD 1945 sebagai suatu konstitusi dengan mengacu kepada prinsip-prinsip negara hukum, masih berbau kolonialistik.

Kebijakan pemerintah pusat yang terkadang menggusur pemilikan hak-hak atas tanah rakyat. Hal ini, akan lebih menyinggung bilamana tanah-tanah yang dijadikan sasaran pembangunan dikuasai oleh kelompok masyarakat dari suatu agama tertentu. Seperti, tanah lot yang terdapat candi diaturnya untuk dijadikan tempat wisata. Tiadanya perlindungan kuat terhadap hak-hak pemilikan saläh satu disebabkan oleh UU No 5 Tahun 1960 (Undang-Undang PokokAgraria). Dalam Pasal 3 disebutkan bahwa hak milik atas tanah memiliki fungsi sosial. Artinya, tanah dan bangunan di atasnya seperti candi-candi mesjid dapat dikuasai oleh pemerintah. Usaha untuk mempermudah jalannya keinginan kepentingan umum didukung oleh Keppres No 55/tahun 1993, sebagai usaha pemerintah untuk membebas- kan tanah untuk pelaksanaan pembangunan demi kepentingan umum begitu mudah. ${ }^{13}$

UU No 5/ tahun 1974 dirasakan telah menggeser hak-hak adat. Bilamana dilihat dari segi tuntutan masyarakat global jelas tidak aspiratif. Lebih parah adalah ketika masyarakat harus menyerahkan tanah-tanah milik mereka oleh karena adanya suatu proyek pembangunan. Banyak kasus, seperti waduk Kedung Ombo, Jawa Tengah, kasus Nipa di Madura telah menyinggung martabat masyarakat lokal. Ketidakpuasan masyarakat, bukan sekedar disebabkan oleh tidak sepadannya kompensasi (ganti rugi) melainkan cara pencabutan hak bukan oleh undang-undang. Suatu proses penarikan hak-hak rakyat, yang dilakukan melalui suatu Keputusan Presiden (Keppres), Surat Keputusan Gubernur atau Bupati bernuansa penekanan (repressive). Bilamana hak pemilikan itu dilindungi oleh undang-undang, maka pencabutan hak-haknya itu juga harus mestinya menggunakan kekuatan yang sejajar. Dengan demikian, bilamana cara-cara hukum ditepati, maka aspirasi rakyat melalui lembaga legislatif dapat diakomodir. Ini juga berarti akan menimbulkan tegaknya pemberdayaan peranan DPR Pusat dan Daerah dalam ketertiban ternyata menyelesaikan suatu pertikaian.

\section{Aspirasi Global}

Kebijakan-kebijakan negara yang seakanakan konstitusional tampak tidak sesuai dengan arus masyarakat internasional. Tidak

${ }^{13}$ Lihat lebih detil, J. Thontowi. 1995. "Reformasi dan Kompilasi Peraturan Hukum Kerukunan antara Ummat Beragama". di dalam Hanafi Sofyan. Indonesia dalam Transisi: Tantangan dan Perubahan Setelah 50 tahun Merdeka. Canberra-Jakarta. Halmahera Foundation. Hlm 168. 
saja terkait dengan segi-segi pelanggaran peraturan hukum ekonomi internasional, lebih dari itu banyaknya pelanggaran HAM.

Kebijaksanaan pemerintah melalui Instruksi Presiden (Inpres) No 2 Tahun 1996 mengenai mobil nasional Timor memang dapat menguntungkan pihak Indonesia. Tidak dikenakannya biaya pajak ekspor memungkinkan tersedianya mobil dengan harga murah bagi masyarakat. Tapi kebijakan tersebut menimbulkan reaksi internasional, khususnya para produsen atau pemegang saham dalam bidang otomotif yang telah mengembangkan kiprahnya begitu lama. inpres tersebut telah bertentangan dengan ketentuan hukum internasional dalam WTO (World Trade Organization). Misalnya, organisasi JAMA (Japan Automobile Manufactures Association $(\mathrm{nc})$ memprotes keras dan mengancam untuk memperkarakannya di Mahkamah Internasional, ICJ (International Court of Justice). Tidak lama kemudian, PT Mobil Timor yang dipimpin oleh Tommy Suharto bangkrut seiring dengan jatuhnya kekuasaan Suharto sejak $21 \mathrm{Mei}$ 1998. Adanya korupsi di dalam Kasus Mobnas Timor itu hingga kini masih berada dalam penanganan pengadilan.

Pelanggaran yang melibatkan konglomerat dan beberapa pejabat yang terlibat dalam perusahaan negara turut juga dikritik masyarakat internasional karena keterlibatannya dalam praktek monopoli, dan kartel. Misalnya, sebagaimana dikemukakan oleh Dorojatun Kuntjarajakti dan De Tray, kepala Lembaga keuangan PBB. Sebab, praktek monopoli dan oligopoli, dan kartel (gabungan produsen atau konglomerat Indonesia untuk menentukan harga tanpa mempertimbangkan WTO sungguh tidak menguntungkan. Sementara itu, kedudukan pemerintah Indonesia masih ter- gantung kepada Peranan Bank Dunia dan Dana Moneter Internasional. Lantaran praktek tersebut bertentangan dengan hukum internasional maka boleh jadi jasa baik lembaga internasional, pengucur dana bisa memberhentikannya. Padahal situasi ekonomi dan politik dewasa ini semakin rumit bila dibandingkan sekitar 30 tahun yang lalu. Beberapa sarjana Bank Dunia telah mengkritik kebijaksanaan pemerintah mengenai Bulog (Badan Usaha Logistik). Bulog dianggap tidak komitmen dalam melaksanakan peraturan General Agreement On Tarrif dan Trade). Paul D Wolfowitz, Mantan Duta Besar Amerika Serikat Indonesia sebaiknya memprioritaskan pembangunan dan hak azasi manusia. Memang negara lain tidak bisa turut campur ke dalam. Tapi saya juga mengerti bahwa bahaya akan tetap -mengancam Indonesia.

Selain itu, Indonesia sebagai peringkat kedua terburuk setelah RRC dalam penanggulangan lingkungan tidak dapat diabaikan bila kita menghendaki agar kredibilitas sebagai bangsa yang moderen diakui bangsabangsa lain. Penilaian masyarakat intemasional ini turut menentukan martabat bangsa yang apabila hasil Pemilu 7 Juni 1999, termasuk pemerintahan reformasi yang baru tidak segera memulihkan kepercayaan dan integritas bangsa di mata intemasional.

Lebih berat dari itu, citra global Indonesia ini berkaitan dengan proses penggembosan hadirnya profesionalisme di dalam tubuh penegak-penegak hukum, polisi RI. Situasi ini timbul salah satunya diakibatkan oleh adanya tumpang tindih fungsi ABRI dalam memulihkan ketertiban masyarakat (Kamptibmas).

Bilamana kita telah secara seksama, terlihat jelas bahwa pasal-pasal mengenai kedautatan rakyat, dan usaha-usaha membela 
rakyat tidak sebanding. Hak-hak rakyat yang semestinya dijamin oleh negara dan diberikan perlindungan ke arah terciptanya kesejahteraan sosial (social welfare) relatif sangat sedikit. Kepedulian pemerintah indonesia dalam hukum Hak Asasi Manusia (HAM) Internasional terhitung masih rendah. Terbukti dengan laporan dan Lawrence W. Beer, mencatat pada tahun 1992 Indonesia tergolong negara besar, namun hanya meratifikasi sekitar 4 macam hak-hak azasi manusia internasional. Meskipun jumlah banyaknya ratifikasi HAM tidak selalu menjadi indikasi sedikitnya pelanggaran, dalam konteks Indonesia banyak memiliki hubungan positif. Misalnya, Fiji telah meratifikasi HAM internasional sekitar 12 macam, dan Philipine 16 macam.

Segi penting lainnya, dalam konvensi ketatanegaraan yaitu dominasi militer dan berakibat banyaknya pelanggaran terhadap HAM adalah karena mereka telah menggeser peranan polisi sebagai penegak ketertiban masyarakat. Pandangan ini dianggap bahwa Dwi fungsi ABRI dalam bidang penegakan ketertiban disebut sebagai Double Instifutionalization of Law. Akibatnya, penanganan kasus dengan melanggar HAM terus terjadi berulangkali bahkan dengan cara-cara rekayasa hukum. Situasi ketidakadilan hukum yang menimbulkan rasa ketidakpuasan masyarakat juga didukung kebiasaan dipraktekannya ancaman dan penggunaan kekerasan (physical Abuse) pada proses investigasi di tingkat kepolisian.

Faktor kedua dari implikasi dominasi Tentara Nasional Indonesia (TNI) adalah timbulnya praktek konspirasi di dalam dan di luar pengadilan. Istilah rekayasa (orchestrasize) dan kambing hitam (scape goat), dan provokator atau master of mind adalah karak- teristik baru yang menimbulkan budaya hukum yang destruktif. Praktik yang bersifat politik praktis ini telah menjadi rahasia umum dan berakibat hilangnya kepercayaan masyarakat terhadap sebagian putusan pengadilan. Lembaga inkonstitusional, seperti Komando Keamanan dan Ketertiban (KOPKAMTIB) meialui Keputusan Presiden (Keppres) No 3 Oktober 1965, dan Badan Koordinasi Ketahanan $\mathrm{Na}-$ sional (Bakortanas) melalui Keputusan Presiden (Keppres) No 29 Tahun 1988 telah melahirkan wajah kekerasan seakan-akan identik dengan hukum. Dalam era reformasi, lembaga yang hampir serupa juga muncul yaitu Dewan Penegakkan Keamanan dan sistem hukum, lembaga ini sebagai tercatat dalam RUU PKB (Penanggulangan Keadaan Bahaya) telah dirubah dijadikan institusi yang memberi masukan konsep kepada presiden.

Pengaruh negatif dari peranan dominan militer ini telah menambah besarnya peluang intervensi lembaga eksekutif ke lembaga peradilan. Sehingga mekanisme kerja penegak hukum yang monoloyalitas semakin menjauhkan tercapainya keadilan masyarakat. Pertama, pengaruh Dwifungsi TNI ketidakberdayaan penegak hukum, salah satunya adalah hilangnya kewibawaan polisi dalam mekanisme penegak hukum. Secara de facto, TNI ini dalam mekanisme hukum diànggap sebagai tandingan (counter action) di luar wewenang institusi hukum. Situasi Dwifungsi TN! tidak mudah dihapuskan oleh karena dianggap sebagian konvensi dalam praktek ketatanegaraan dalam pemerintahan Orde Baru. Dari aspek kesejarahan, TNI telah berhutang budi kepada sipil dan mengembalikan UUD 45 (Dekrit 5 Juli 1959) dan mempertahankan ideologi Pancasila. Kehidupan bermasyarakat, berbangsa, bernegara harus terpelihara serta ber- 
jalan dengan aman dan tertib. Berdasarkan pendekatan empiris, sosiologis, selama ini terdapat proses penguatan atas hak monopoli TNI yang merasa sebagai satu-satunya institusi yang paling berhak untuk menilai dan menentukan sepihak, sesuai doktrin-doktrin militerisme situasi dalam keadaan aman atau tidak aman, yang secara konseptual dalam nuansa akademik, kriteria aman dan tertib. ${ }^{14}$

Usaha pengurangan Dwi fungsi TNI terlihat dari pembatasan utusan TNI di MPR/ DPR. Namun niat baik itu menjadi sirna ketika RUU PKB dipaksa untuk disahkan. Salah satu alasannya, karena juga selain telah memiliki ciri, mengagungkan struktur negara, juga peranan ABRI begitu dominan dalam kaitannya dengan pensiun tidak sipil. Reaksi balik demonstrasi mahasiswa tidak bisa dihindarkan. Empat orang menjadi korban akibat pertikaian antara petugas keamanan dan demonstran. Akibat demonstrasi tersebut UU PKB hingga kini belum bisa diundangkan.

\section{Simpulan}

Praktek Pemerintahan Orde Baru yang berlandaskan kepada prinsip-prinsip negara hukum terbukti telah menciptakan Indonesia dalam bentuk negara hukum yang bersifat Konstitusional. Autoritarisme. UU sebagai produk legislatif, Keppres dan Peraturan lainnya, telah nyata-nyata tidak sedikit dipergunakan untuk membenarkan kehendak penguasa. Praktek pemerintah Orde Baru tercermin dalam pengalaman ternyata tidak sesuai dengan tuntutan arus globalisasi. Hal ini karena pemerintah Orde Baru telah memiliki andil besar dalam menciptakan suatu kepercayaan atas pengsakralan Pancasila, ideologi negara dan UUD 45. Kenyataan ini bertentangan dengan UUD 45, Pasal 37 dan juga tidak mampu mengikuti arus globalisasi baik untuk kepentingan nasional, individu, suku, golongan, agama, dan memelihara tegaknya peraturan hukum Internasional (dalam ekonomi dan hakhak azasi manusia).

Karena itu, cita-cita yang mesti kita bangun tidak sekedar merubah keyakinan masyarakat dalam kaitannya supremasi hukum, melainkan juga amandemen terhadap UUD 1945 (batang tubuh) menjadi target yang perlu dibicarakan dalam Sidang Umum MPR saat ini. intervensi kekuasaan Presiden terhadap kedudukan MPR/DPR, juga terhadap lembaga peradilan sebagaimana diatur dalam UUD 45 jelas-jelas tidak mendukung tegaknya prinsip-prinsip pelaksanaan negara húkum. Perlindungan UUD '45 terhadap hak-hak individual, pelayanan yang adil terhadap keberadaan masyarakat yang pluralis, serta perlindungan terhadap HAM mutlak harus diakomodasikan.

Supremasi hukum akan diperoleh bilamana perubahan UUD 1945 dan hukum, (baik secara konseptual maupun fungsional) diikuti dengan usaha-usaha penciptaan suasana penegak hukum yang mampu bekerja secara profesional. Dwi fungsi ABRI, dan berbagai Kebijakan Pembentukan lembaga, termasuk Dewan Penegakan Keamanan dan Ketertiban hukum perlu dihapuskan bukan sekedar

${ }^{14}$ Tim Fakultas Hukum Ull. 1999. RUU Keselamatan dan Keamanan Negara Beberapa Catatan untuk Perubahan Terhadap FPP DPR RI. HIm 2. 
timbulnya tumpang tindih fungsi $A B R I$ dengan penegakan hukum, melainkan juga sudah saatnya penegak hukum Indonesia dalam pemerintahan reformasi ini menegakkan jati dirinya.

\section{Daftar Bacaan}

Beer, Lawrence W. ND. Constitutional Systems in Late Twentieth Century Asia. London: Univercity of Washington Press.

Friedman, Lawrence. 1969. The Legal System: A Social Science Perspective. New York: Russel Sage Foundation.

Hickling. 1995. Major Legal Systems. Centre for Southeast Asian Studies, Northern Territory University.

Hooker. 1978. A Consice Legal History of Southeast Asia. Oxford: Clarendon Press.

Kung, Hans. 1991. Global Responsibility: In Search of a New World Ethics. New York: Crossroad.

Lev, Daniel S. 1999. KOMPAS. September. Mahendra. 1996 Dinamika Tatanegara Indonesia. Jakarta: Gema Insan Press.

Merry, Sally Engle. 1988 Legal Prulalism. Law and Society Riview, Vol $22 / 5$.
O'Hogan, Timothy. 1984. The End of Law. Oxford: Basill Blackwell.

Philipus M. Hadjon. 1996. Ide negara Hukum Dalam Sistem Ketata Negaraan

Republik Indonesia. di dalam Bagian Kedaulatan Rakyat Hak Asasi Manusia dan Negara Hukum. Kumpulan Esai Guna Menghormati R Sri Soemantri Marto Soewigyo, SH. Jakarta: GMP.

Globalization in Turner, Bryans (ed) Theories of Modernity and Post-Modernity. London Sage Publications

Thontowi, J. 1997. Law and Custom: The Interaction of Local Custom and the

Indonesian Legal System in Dispute Resolutions. Ph.D Thesis, Department of Anthropology, UWA. Nedlands.

Thontowi, J. 1995 Reformasi dan Kompilasi Peraturan Hukum Kerukunan antara

Ummat Beragama, di dalam Hanafi Sofyan. Indonesia dalam Transisi: Tantangan dan Perubahan Setelah 50 tahun Merdeka. Canberra-Jakarta: Halmahera Foundation.

Tim Fakultas Hukum Uil, 1999 RUU Keselamatan dan Keamanan Negara Beberapa Catatan untuk Perubahan. Terhadap FPP DPR RI. 